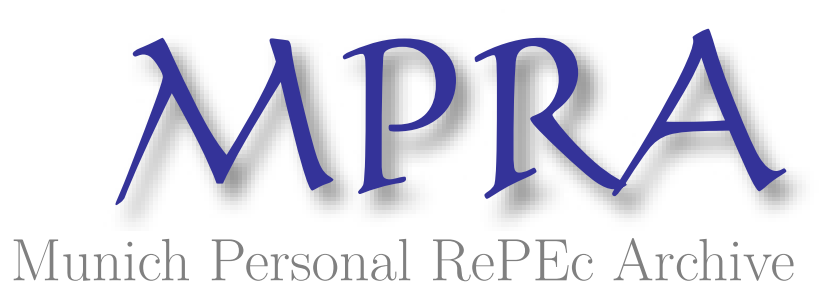

\title{
Corporate governance research in Nigeria: a review
}

Ozili, Peterson K

19 January 2020

Online at https://mpra.ub.uni-muenchen.de/103236/

MPRA Paper No. 103236, posted 06 Oct 2020 09:20 UTC 


\title{
Corporate governance research in Nigeria: a review
}

\section{Peterson K Ozili}

Financial System Stability (FSS) Directorate, Central Bank of Nigeria.

\begin{abstract}
This paper analyzes the state of corporate governance (CG) research in Nigeria. It consolidates the literature to identify the current state of CG research in Nigeria and to identity opportunities for future research in the literature. Among other things, the review show that the Board of directors (BOD) is the most explored corporate governance mechanism in the Nigerian corporate governance literature. Secondly, most studies focus on some governance mechanisms but ignore other governance mechanisms in firms. Thirdly, there is some consensus that the corporate governance failures in Nigeria is caused by multiplicity of factors mainly, lack of political will by the government to enforce corporate governance laws, deliberate refusal to comply with existing CG laws by politically connected firms, weak compliance by firms, weak enforcement by regulators, and conflicting codes in the country's corporate governance codes. Also, the review shows that current CG studies do not systematically build on previous Nigerian CG studies which indicates a lack of direction in the Nigerian corporate governance literature. Regarding methodology, the findings reveal that most Nigerian CG studies are merely experimenting different methods of analysis without necessarily advancing the literature in a significant way. These findings have implications.
\end{abstract}

Keywords: Corporate governance, Nigeria, Africa, firm performance, ownership structure, Board size, gender diversity, bank profitability, tobin Q, audit committee

JEL: G30, L26, M10

This version: January, 2020.

All comments on this article should be directed to PKOZILI@cbn.gov.ng. The conclusions in this article are those of the author, and does not reflect the policy thinking of the Board of Governors or the management of the Central Bank of Nigeria. 


\section{Introduction}

Corporate governance (CG) is crucial for the survival and performance of firms in Nigeria and its determinants continue to receive much attention from academics and regulators. The last two decades witnessed the failure of many financial and non-financial firms in Nigeria such as Oceanic bank, Intercontinental bank, NITEL and Vodafone. These corporate failures in Nigeria led to increased interest in corporate governance research focusing on Nigerian firms, consequently, much studies have been done on corporate governance in Nigeria. I identify the need to bring together in one article the recent developments in corporate governance research in Nigeria. To do this, I review the studies that investigate corporate governance in Nigeria to identify the recent advances and challenges in the literature and identify possible directions for future research with some concluding remarks.

In the broad CG literature, existing studies have examined some theories of corporate governance (see Fama and Jensen, 1983; Jensen and Meckling, 1976; Clarke, 2004; Aguilera et al, 2018); the impact of CG on firm performance (see Keasey et al, 1994; Del Brio et al, 2006; Zattoni et al, 2017), the impact of CG on the performance of small and medium enterprises (SMEs) (see Cowling, 2003; Abor and Adjasi, 2007; Ahn, 2014); CG in emerging economies (Claessens and Yurtoglu, 2013) and good codes of corporate governance in several country, regional and international contexts (Reid, 2003; Zattoni and Cuomo, 2008; Von Werder et al, 2005; Salterio et al 2013; etc.). Despite the extensive research on CG, yet many African studies, are either unnoticed in the literature or are largely ignored and therefore the findings from African studies have been exempted from mainstream academic corporate governance discussions. For instance, a quick search on Google Scholar using CG keywords reveal that Nigeria has the highest number of CG studies in Africa, followed by Ghana, and then South Africa and Kenya - in that order. A further search using Nigeria* and $\mathrm{CG}^{*}$ as keywords also reveal that the Nigerian $\mathrm{CG}$ literature is not only much but is also saturated, indicating that there is sufficient content to conduct a systematic review. Therefore, in this review, I focus on the Nigerian corporate governance literature. So far, there are no reviews on the state of CG research in Nigeria, and I believe that the Nigerian corporate governance literature has reached a level of saturation such that a systematic review can help to consolidate the achievements in the literature and craft a research agenda for years to come.

This review offers multiple opportunities and benefits to researchers and practitioners by highlighting the importance of corporate governance research in Nigeria and by revealing patterns in theory, data, methodology, and content. The review then discusses future research possibilities. I highlight how existing research is fragmented in a range of disciplinary fields including finance, corporate governance, and management. Finally, the remarks on the challenges and prospects of CG research in Nigeria in this review article are limited to issues in the literature that I find to be particularly significant. My aim in 
this review is to elicit comments and stimulate debates that can potentially advance CG research in the broader CG literature.

The discussions in this review article contributes to the literature in the following way. One, it contribute to the literature that examine the link between corporate governance and firm performance (e.g. Kor and Mahoney, 2005; Kroll et al, 2007). There is some evidence that certain CG determinants in Nigeria improves firm performance while other CG determinants worsen the performance of some firms. Two, by relating CG to managerial behavior, this review contributes to the literature that examine how certain CG structures can encourage managers to influence their profit levels to improve firm performance (Leuz et al, 2003; Klein, 2002, Ozili and Outa, 2017). Three, the survey contributes to the literature that examine the role of institutional monitoring and corporate governance in enhancing firm performance.

The rest of the paper is structured as follows. Section 2 presents an overview of the state of corporate governance in Nigeria. Section 3 highlight the common theories used in the literature. Section 4 explores the consequence of $\mathrm{CG}$ in the empirical literature. Section 5 discuss the evidence on corporate governance determinants. Section 6 highlights some measurement and methodological issues. Section 7 presents some directions for future research. Section 8 concludes.

\section{Corporate governance in Nigeria: an overview}

\subsection{Pressure to develop good national code of corporate governance}

Good corporate governance is good for business. It can attract foreign investments to Nigerian firms. But for this to happen, investors must trust the legal system in Nigeria and its ability to protect minority shareholders. Ahunwan (2002) show that Nigeria has been facing increasing international economic pressure to adopt a responsible corporate governance system and a program of economic liberalization and deregulation. This will help to improve investors' confidence in doing business in Nigeria. Nigeria has an evolving code of corporate governance. Any corporate governance code of best practices adopted in Nigeria should reflect the unique socio-political and economic situation in Nigeria while at the same time providing the right assurance to current and potential shareholders (Okike, 2007). Also, it is expected that Nigeria's code of corporate governance will be somewhat different from the corporate governance laws in modern economies. This is because the peculiar nature of developing economies, like Nigeria, will make the running of many private companies different from the governance processes of private companies in modern economics which are controlled, at least in principle, by the owners through shareholder democracy through participation in the annual general meetings (Yakasai, 2001). 


\subsection{The Nigerian Code of Corporate Governance (NCCG)}

In 2019, Nigeria issued a new Code of corporate governance for private companies, public companies and not-for-profit entities. The new $\operatorname{Code}^{1}$ is made up of 7 parts and contains 28 principles. It covers the 'Board of directors', 'audit', 'relationship with shareholders', 'business conduct with ethics', 'sustainability', 'transparency' and 'definitions'. The Code is principle-based and requires the "apply and explain" approach. All companies are required to comply with the Code and explain the reasons for not adopting them. The purpose of using the 'apply or explain' approach is to encourage better corporate governance practices among Nigerian Companies. The issuer of the code, the Financial Reporting Council of Nigeria, will monitor the implementation of the Code in collaboration with sectoral or industry regulators, while the sectoral regulators have been empowered to impose appropriate sanctions for violations of the Codes based on sectoral or industry laws and regulations.

The new code which was issued on $15^{\text {th }}$ January 2019 improves on the previous code in three key areas namely: (i) by specifying an effective whistle-blowing framework for reporting any illegal or unethical behavior; (ii) by requiring companies to pay attention to sustainability issues including environment, social, occupational and community health and safety; (iii) and by promoting full and comprehensive disclosure and transparency to investors and stakeholders.

The new Code is being criticized for failing to make a distinction between public and private companies. Currently the new code is applied to all companies and non-profit entity regardless of its business form. Critics argue that there should be separate codes or sub-codes for private companies, public companies and for non-profit companies because of the structural differences in the way the three entities operate, and because of differences in capacity to implement the codes by the three entities. Secondly, the code is heavily criticized because it did not specify any date for implementation. This criticism is reasonable because ideally codes of corporate governance should have a date for implementation.

\subsection{Current reality in Nigeria}

The unique business environment in Nigeria will influence its adoption of any corporate governance code or laws. Nigeria's peculiar institutional arrangements will influence its model and style of corporate governance regulation, and these institutions can either promote good corporate governance or can constitute barriers to the implementation of good governance principles in Nigeria (Adegbite, 2012). The current reality in Nigeria is that Nigeria has institutions that govern the behavior and activities of managers of firms, but these institutions have little or no enforcement powers to discipline rule-breaking firms because the managers of rule-breaking firms are often politically-connected to top

\footnotetext{
${ }^{1}$ The code is available at: https://pwcnigeria.typepad.com/files/nigerian-code-of-corporate-governance-2018-1.pdf
} 
government officials or may bribe their institutional supervisor or regulator to evade sanctions. Oyejide and Soyibo (2001) share a similar thought with me on this issue, they analyze the state of corporate governance in Nigeria and conclude that Nigeria has institutions and the legal framework needed for effective corporate governance but compliance and/or enforcement appear to be weak or non-existent in Nigeria.

Another issue in implementing corporate governance in Nigeria is the different interpretations of the code of corporate governance in Nigeria. Different agents especially managers, lawyers and the courts, all have different interpretations of corporate governance practice in Nigeria (Adegbite et al, 2013) and this has been a long standing issue. Another issue is the multiplicity of regulations that hinder the workings of existing corporate governance codes. In banks, for instance, the banking regulator require banks to adopt its own corporate governance codes, which conflicts in some areas with the national codes of corporate governance. Osemeke and Adegbite (2016) use the conflict-signaling theory to analyze the areas of conflicts in the various codes of corporate governance in Nigeria and the associated implications for corporate governance practices and regulatory compliances by public-listed Nigerian firms. They find that there is conflict among the various codes of corporate governance in Nigeria, and such conflicts contribute to the reduced compliance by firms and the ineffective enforcement by regulatory agencies, which together impede good corporate governance in Nigeria.

\subsection{Cause of corporate governance failures}

One question that emerge is: what is responsible for corporate governance compliance failures in Nigeria? There are many answers to this question. For instance, Adekoya (2011) argue that the corporate governance failure is caused by the country's culture of institutionalized corruption, political patronage and the refusal of government agencies to enforce and monitor compliance. Another cause of corporate governance failure is corruption in the business environment (Letza, 2017). Nwidobie (2016) claim that the corporate governance problems in Nigeria are caused by self-interested controlling shareholders as well as controlling shareholders who are also directors. Nwidobie (2016) argue that, to redress this situation in listed Nigerian firms, shares of closely held firms should not be traded on the exchange; the maximum shareholding by an individual be at a maximum of $25 \%$; the capital market and firm regulators should verify the accuracy of disclosures to ensure they are not only made to comply with regulations but to instill good corporate governance practices in Nigerian firms. Abdulmalik and Ahmad (2016) claim that corporate governance weakness and failure in Nigeria is due to conflicting regulatory laws and the impairment of Board of directors and auditor independence arising from the nature of firm ownership structure in Nigeria. Okpara (2016) argue that weak or non-existent law enforcement mechanisms, abuse of shareholders' rights, lack of commitment on the part of Board of directors, lack of adherence to the regulatory framework, weak enforcement and monitoring systems, and lack of transparency and disclosure are causes of CG failure in Nigeria. 


\section{Corporate governance theories}

Many studies do not use a theoretical perspective to describe the CG relationship they are investigating (e.g. Uadiale, 2010; Letza, 2017, etc.). Only few studies use well-developed theories in their CG analyses. Among these studies, agency theory and institutional theory are the most common theories used in the Nigeria CG literature. Agency theory was used in Fodio et al (2013), Sanda et al (2005), Abdulazeez et al (2016), Ozili and Uadaiale (2017) and Paul et al (2015). Agency theory is concerned with the separation of ownership and control. It argues that managers are driven by self-interest and will act against the interest of shareholders, for this reason, the monitoring of management or compensation incentives can ensure that managers align their interests with shareholders' interest (Fama and Jensen 1983; Jensen and Meckling 1976).

Few studies use institutional theory such as Adegbite (2015) and Adegbite and Nakajima (2011). Institutional theory explains how formal and informal institutions shape the corporate governance practices of firms (Zattoni et al. 2017; Lynall et al. 2003). It explains how corporate governance is affected by external institutions such as the national institutional environment and the political institutional environment (e.g., Ge et al. 2017; Zattoni et al. 2017). Also, there are other theories which have not been extensively used by studies investigating CG in Nigeria such as the stakeholder theory of corporate governance (John and Senbet, 1998), resource theory, social network theory (Lynall et al, 2003), contingency theory, upper echelon theory, grounded theory, and so on.

\section{Consequences of corporate governance}

\subsection{Effect on firm performance}

Mohammed (2012) examine the impact of corporate governance on the performance of nine (9) Nigerian banks from 2001 to 2010, and find that strong corporate governance improves bank performance while poor asset quality (defined as the ratio of non-performing loan to credit) and loan deposit ratios negatively affect bank performance. Sanda et al (2005) investigate the role of good corporate governance mechanisms in improving the performance of firm financial firms. They examine 93 listed firms in Nigerian from 1996 to 1999. They use a pooled ordinary least squares regression estimation, and find that firms run by expatriate CEOs perform better than firms run by indigenous CEOs. Ehikioya (2009) examine the relationship between corporate governance structure and firm performance in Nigeria. They analyze 107 listed firms in the Nigerian Stock Exchange from 1998 to 2002, and find that ownership concentration has a positive impact on performance while CEO duality and having more than one family member on the Board negatively affects firm performance. 
Babatunde and Olaniran (2009) examine the role of corporate governance for firm performance among 62 listed firms during the 2002 and 2006 period. They find that Board size negatively affects firm performance. They recommend that regulatory agencies should encourage firms to have a reasonable Board size. Paul et al (2015) assess the impact of corporate governance (CG) on microfinance bank's financial performance in Nigeria. In their OLS regression analyses, they did not find a significant relationship between corporate governance and bank's financial performance. Nwaiwu and Joseph (2018) investigate the relationship between core corporate governance and financial performance of quoted manufacturing companies in Nigeria from 2012-2016. The results indicate that audit committee members have a significant effect on profitability measured as earnings per share and return on assets. They conclude that the Board needs to comprise of well-educated people since they are actively involved in shaping company's strategy. The study recommends that non-executive directors should be trained on internal corporate governance mechanisms.

Uwalomwa et al (2015) investigate the relationship between corporate governance mechanisms and the dividend payout policies of firms in Nigeria. The findings reveal that Board size, ownership structure, CEO duality and Board independence has a significant positive effect on the dividend payout decisions of the sampled firms, while Nwidobie (2016) find that corporate governance has no impact on the dividend policies of Nigerian firms. Amahalu et al (2017) examine the effect of corporate governance on firms' borrowing cost from 2010 to 2015. Corporate governance was measured using three indicators: Board size, ownership concentration and Board independence. They find that Board size, ownership concentration and Board independence have a positive and significant effect on borrowing cost by decreasing the firms cost of capital. Oyewunmi et al (2017) find that there is a significant relationship between corporate governance practices and human resource management outcomes in Nigeria's downstream petroleum sector. Odeleye (2018) investigate the relationship between corporate governance and dividend payout in Nigeria for 97 non-financial listed companies in Nigeria from 1995 to 2012 , and find a significant positive association between corporate governance and dividend payout.

\subsection{Effect on earnings management}

In theory, strong corporate governance will exert additional monitoring on managers to discourage the manipulation of accounting numbers for earnings management purposes (Leuz et al, 2003; Klein, 2002). Some Nigerian studies show some evidence that corporate governance can have either positive or negative effects on earnings management. For instance, Uwuigbe et al (2014) examine the effect of corporate governance mechanism on earnings management in Nigeria from 2007 to 2011. Earnings management was measured using discretionary accruals in the study. They find that Board size and Board independence have a significant negative impact on earnings management. CEO-chair duality also had a significant positive impact on earnings management. They conclude that firms with larger Boards and diverse knowledge are more likely to be effective in constraining earnings management 
than smaller Boards because larger Boards are more likely to have higher numbers of independent directors with more corporate or financial expertise.

Uadiale (2012) examine the role of the Board of directors and audit committee in preventing earnings management in Nigeria. The findings reveal that Boards dominated by outside directors brings a greater breadth of experience to the firm and are in a better position to monitor and control managers thereby reducing earnings management. Uadiale recommends that Board composition should include greater proportion of independent outside directors with corporate experience. Audit committee members should be encouraged to possess a certain level of financial competencies to decrease the likelihood of earnings management. Abdulmalik and Ahmad (2016) examine whether good corporate governance improves financial reporting quality, and find that the presence of independent non-executive foreign directors on a Board improve financial reporting quality and an increase in the percentage of share ownership of foreign institutional shareholders also improve financial reporting quality.

Usman and Yero (2012) examine the impact of ownership concentration and earnings management practice in listed Nigerian firms. They find a significant negative relationship between ownership concentration and earnings management. Dibia and Onwuchekwa (2014) examine the association between corporate governance mechanisms and earnings management in Nigeria and find that corporate governance, particularly Board size, is negatively associated with earnings management, implying that having a larger Board size can reduce the level of earnings management in Nigeria. Ojeka et al (2014) examine the influence of audit committee effectiveness on firm's performance using four characteristics: independence, financial expertise, size, and meetings of the audit committee. They find that firms that have an independent and knowledgeable audit committee experience higher profitability.

\subsection{Effect on financial reporting}

Damagum et al (2014) show that the quality of financial reporting improves when there is a higher number of women in the Board of firms. Moses et al (2016) examine the influence of corporate governance on financial reporting quality in listed Nigerian banks. They focus on audit committee characteristics as the main corporate governance variable. They find that audit committee independence has no significant effect on earnings management in listed Nigerian banks. Kantudu and Samaila (2015) examine the impact of Board characteristics and independent audit committee and financial reporting quality for 12 oil companies during 2000 to 2011. They find that power separation, independent directors, managerial shareholdings and independent audit committee significantly improve the quality of finance reporting in Nigeria. 


\subsection{Effect on information disclosure.}

Strong corporate governance can exert additional monitoring on firms and can pressure managers to increase the quality and quantity of information disclosure to shareholders and outsiders in order to reduce the information asymmetry between owners and managers. Studies investigating the effect of corporate governance on information disclosure in Nigeria are very few. For instance, Odoemelam and Okafor (2018) examine the influence of corporate governance on environmental disclosure in nonfinancial firms listed in the Nigeria Stock Exchange (NSE). Using the "trinity theory" (agency, stakeholder and legitimacy theories). They find that Board independence, Board meeting, firm size and the environmental committee have a significant effect on environmental disclosure while audit committee independence, having a Big4 auditor, Board size and industry membership had an insignificant effect on environmental disclosure. Adebimpe and Peace (2011) examine the effect of corporate governance on voluntary disclosures among Nigerian listed companies. They find that some corporate governance attributes have a significant positive relationship with the extent of voluntary disclosures while other corporate governance attributes such as Board composition, leverage, company size, profitability, and auditor type do not have a significant effect on voluntary disclosure. Foyeke et al (2015) examine the effect of corporate governance disclosure on firm performance during the period when corporate governance disclosure was a voluntary requirement for companies in Nigeria. They analyze 137 financial and non-financial companies, and find a significant positive relationship between the financial performance and the size of corporate governance voluntary disclosure.

\subsection{Effect on Nigerian banks}

Banks are special financial institutions because they deal with depositors' money, and in practice, banks take excessive risk with depositors' money (Ozili and Outa, 2017). Given their special nature, banks need a unique corporate governance structure in addition to other regulations to ensure that banks' risktaking do not put depositors' money at risk. In recent years, Nigerian banks have a different corporate governance structure from non-financial firms. They have a larger Board and a lower fraction of insiders than non-financial firms, and the Boards of Nigerian banks are more independent than the Boards of nonfinancial firms. The unique corporate governance structure of Nigerian banks was introduced by the Central Bank of Nigeria in 2005. Some argue that good corporate governance is needed in banks to effectively manage the resources of bank particularly where there is management/shareholders separation (Mohammed, 2012).

One significant observation in the literature is the small sample size and the small number of banks which is commonly used to test the effect of corporate governance on bank performance in existing studies. The narrow sample size and small sample period are due to the recent adoption of corporate governance codes for Nigerian banks. For example, Abdulazeez et al (2016) examine the impact of corporate governance on the financial performance of all listed deposit money banks in Nigeria using 
the Pearson correlation and regression. They find that a larger Board size contributes positively and significantly to the financial performance of deposit money banks in Nigeria. They recommend that banks should increase their Board size but within the maximum limit set by the code of corporate governance. Okpara and Iheanacho (2014) investigate the impact of corporate governance on the banking sector performance using discriminant analysis, correlation coefficient and the spearman rank correlation as an alternate method. They find that foreign ownership positively improves bank performance. Hassan (2011) examines the effect of corporate governance mechanisms on the financial reporting quality of Nigerian banks. Multiple regression was used as a tool of analysis for the data collected from all the quoted banks on the Nigerian stock exchange. The results reveal that corporate governance mechanisms have a positive and significant effect on financial information quality in Nigerian banks. Ozili and Uadiale (2017) also investigate the role of corporate governance in Nigerian banks, focusing on the effect of ownership structure on bank profitability. They find that banks with high ownership concentration perform better because they have higher return on assets, higher net interest margin and higher recurring earning power while banks with dispersed ownership have lower return on assets but have higher return on equity.

\section{Corporate governance determinants}

\subsection{Board structure and composition}

\subsubsection{Board size and independence}

In theory, there is wide support for having a large Board size and independent Board members (Xie et al, 2003). A small Board size can increase the power of controlling shareholders to influence managers to act in their favour, compared to a large board size. A dependent Board will be unable to make transparent and fair decisions when they have conflicted interest with the firm management, compared to an independent Board. For instance, Sanda et al (2005) argue in favour of having a Board size of 10 members, and also supports concentrated ownership as opposed to diffused equity ownership, but they did not find any evidence to support the idea that Boards with a higher proportion of outside directors perform better than other firms. Uadiale (2010) investigates the impact of Board structure on financial performance, and find that there is a positive association between independent Boards (outside directors sitting on the board) and corporate financial performance. Ehikioya (2009) examine the relationship between corporate governance structure and firm performance in Nigeria and observe that Board composition did not have a significant effect on firm performance while having more than one family member on the Board negatively affects firm performance. Uwuigbe et al (2014) find that firms with larger Boards and diverse knowledge were more effective in discouraging earnings management than smaller Boards since they are likely to have more independent directors with more corporate or financial 
expertise. Babatunde and Olaniran (2009) examine the role of corporate governance for firm performance among 62 listed firms from 2002 to 2006. They find that a large Board size is detrimental to firm performance. They also observe that having outside directors did not help to promote firm performance. They recommend that regulatory agencies should encourage firms to have a reasonable Board size. Kajola (2008) examine the relationship between four corporate governance mechanisms (Board size, Board composition, chief executive status and audit committee) and profitability for 20 Nigerian listed firms between 2000 and 2006. They find a positive and significant relationship between profitability and Board size as well as chief executive status. The study did not find a significant effect for Board composition and audit committee on profitability.

Proponents of gender diversity want greater women participation in the Boards of firms, and some studies show that Boards perform better when there is gender diversity. In Nigeria, Damagum et al (2014) examine the impact of women in corporate Boards on financial reporting quality. They use a sample of 20 listed firms using 2006 to 2011. They find that the presence of a female director does not improve the quality of financial reporting however financial reporting quality improves as the number of women in the Board increases. Overall, these studies above show some consensus that a good having a Board structure and composition improve financial performance in Nigeria.

\subsubsection{CEO-chair duality}

CEO-Chair duality refers to the same individual holding the position of chairman of the Board and the Chief Executive officer (CEO) of the firm. In theory, there is a strong argument for separating the position of the Chief Executive from the position of the Chairman of the Board so that these two positions will be occupied by two different people. When there is duality, the Chief executive will be accountable to himself or herself (who is also the chairman). The individual will become too powerful in the Board, making it difficult for the Board to remove him or her as CEO when the firm is performing badly; hence, the need for separation of CEO and Chairman positions.

Evidence from studies investigating the effect of CEO-chair duality on firm performance in Nigeria are mixed in the literature. For instance, Ehikioya (2009) examine the relationship between corporate governance structure and firm performance for 107 listed firms in Nigeria and find that CEO duality has a negative impact on firm performance. The study recommends the separation of chairman and CEO positions in firms. Ogbechie and Koufopoulos (2007) show that Nigerian public companies have embraced good corporate governance principles and listed companies have medium-sized Boards with separation of the positions of chairman and CEO. Uwuigbe et al (2014) examine the effect of corporate governance mechanism on earnings management in Nigeria from 2007 to 2011 . They observe that there is aggressive earnings management in firms where the same individual holds the positions of CEO and chairman of the Board. 


\subsection{Audit strength - Board audit committee}

Audit committee is a committee that oversee the financial reporting process (DeZoort and Hermanson, 2002). An effective audit committee can enhance corporate governance in firms and can make financial reports become more reliable for investment decisions and policy formulation (Owolabi and Dada, 2011). Miko and Kamardin (2015) suggest that audit committee in firms can help reduce manipulation of financial reports and accounts. Shittu et al (2018) investigate the effect of audit committee independence, abnormal directors' compensation and information disclosure on firm performance measured as price to earnings ratio. They analyze 100 listed firms and find that audit committee independence has a significant positive impact on firm performance. Odoemelam and Okafor (2018) investigate the influence of corporate governance on environmental disclosure of non-financial firms listed in the Nigeria Stock Exchange (NSE). They find that audit committee independence, having a Big4 auditor, Board size and industry membership had an insignificant effect on environmental disclosure. Fodio et al (2013) investigate the effect of corporate governance mechanisms on reported earnings quality of listed insurance companies in Nigeria using 25 listed insurance firms from 20072010. They find that the size of the audit committee is negatively and significantly associated with earnings management while audit committee independence and independent external audit have a positive relationship with discretionary accruals. Joe Duke and Kankpang (2011) show that Nigerian firms that have an audit committee perform better than firms while Uwuigbe (2013) find that firms that have an audit committee have higher share price.

\subsection{Ownership structure}

Ownership structure in Nigerian firms is diverse, fragmented and complex, ranging from controlling ownership, family ownership, political ownership, foreign ownership and institutional ownership. Studies investigating the role of ownership structure on firm performance in Nigeria show mixed evidence on the impact of ownership structure for firm performance. For example, Ehikioya (2009) examine the relationship between ownership structure and firm performance in Nigeria and observe that ownership concentration has a positive impact on performance. Ojeka et al (2016) examine the effect of institutional shareholder engagement on the financial performance of some listed firms from 2011 to 2013, and find that there is no significant relationship between institutional shareholder engagement and firm performance during their period of analysis.

Obembe et al (2016) investigate whether managerial ownership influence the performance of listed nonfinancial firms in Nigeria. They analyze 63 non-financial listed firms between 1998 and 2010, and find that managerial ownership did not have a significant impact on the performance of firms in both the linear and nonlinear estimations. They conclude that managerial ownership is a weak mechanism for mitigating agency problems among firms listed on the Nigerian Stock Exchange. Isaac and Nkemdilim (2016) examine the impact of corporate governance on the performance of Nigerian banks, and find a 
positive and significant relationship between directors' equity holding and banks' performance. Aburime (2008) examine the impact of ownership structure on bank profitability in Nigeria from 1989 to 2004 using t-test analysis, and find that dispersed ownership did not have a significant effect on bank profitability in Nigeria.

Ozili and Uadiale (2017) investigate whether ownership concentration influences bank profitability in Nigeria. Ownership concentration was measured as the amount of shareholders' direct equity holding. They find that banks with high ownership concentration perform better because they have higher return on assets, higher net interest margin and higher recurring earning power while banks with dispersed ownership have lower return on assets but have higher return on equity. To sum, although these studies show conflicting effect of ownership structure on firm performance, it also shows that certain ownership structure can improve the performance of firms in Nigeria particularly higher ownership concentration and higher directors' equity holding.

\section{Methodology and measurement issues}

\subsection{Dependent and explanatory variables}

The most widely used measures of corporate governance in the Nigerian corporate governance literature are Board size, Board independence, audit strength, CEO duality and firm ownership structure while the control variables are bank size and age of the firm (see Abdulazeez et al, 2016; Uwuigbe et al, 2018; Demaki, 2018; Patrick et al, 2015). Board size is measured as the total number of directors on the Board including executive directors and non-executive directors. Firm size is measured as the total assets of the company. Other studies measure firm size as the logarithm of total asset (Ozili and Thankom, 2018; Ozili, 2017). Board independence is measured by the number of independent non-executive directors divided by the total number of directors. The higher the number of independent directors in the Board, the better. Audit Strength is measured as the ratio of total number of audit committee members divided by the total number of directors on the Board. CEO-Chair duality refers to when the chief executive officer (CEO) also holds the position of the chairman of the Board. Finally, ownership structure is measured in different forms. Some studies consider ownership structures from the perspective of controlling shareholders versus non-controlling shareholders (Ozili and Uadiale, 2017) while other studies consider ownership structure from the perspective of foreign ownership versus institutional ownership perspective. 
Regarding financial performance, the most widely used measures of firm performance in the Nigerian corporate governance literature are return on assets (see Ozili and Uadiale, 2017; Adenikinju, 2012; Demaki, 2018; Onakoya et al 2014; Abdulazeez et al, 2016, etc), return on equity (see Onakoya et al, 2014; Ozili and Uadiale, 2017, etc), net interest margin (Adekunle and Aghedo, 2014; Ozili and Uadiale, 2017); Tobin's Q (see Gugong et al, 2014; Adenikinju, 2012; Ujunwa, 2012, etc), recurring earnings power (Ozili and Uadiale, 2017) and earnings per share (see Adefemi et al, 2018; Shittu et al, 2018, etc). Return on asset (ROA) is measured as profit after tax divided by average assets. It measures the ability of firms to generate profit from its operating assets. Return on equity (ROE) is measured as return after tax divided by owners' equity. It measures the profits that shareholders would receive on their invested capital. Net interest margin (NIM) measures the return to banks from interest-generating activities. The Tobin's $Q$ is measured as the market value of equity plus the market value of debt divided by the replacement cost of all assets. Recurring earnings power (REP) measures the ability of a firm or bank to generate income or profits overtime assuming all current operational conditions remain constant and is measured as pre-provision profit excluding net income from financial instruments and sale of securities and tax to average asset ratio. Earnings per share (EPS) represents how much money shareholders would receive for each share of stock they own if the company distributed all of its net income for the period. It is measured as the difference between a company's net income and dividends paid for preferred stock divided by the average number of shares outstanding.

\subsection{Mixed methods and estimation issues}

In the empirical literature, some studies use correlation analysis to test the association between corporate governance and firm performance. These studies draw conclusions based on simple correlations (see Okpara and Iheanacho, 2014; Isaac and Nkemdilim, 2016; etc). One weakness of correlation-based corporate governance studies is that they associate correlation with causation when interpreting their results. Correlation does not imply causation because correlation only describes the directional association between two or more variables - it does not imply causation.

Other studies use the Ordinary Least Square (OLS) regression estimation to estimate the relationship between corporate governance and firm performance (see Usman and Amran, 2015; Patrick, et al, 2015; Nwaiwu and Joseph; 2018; Adigwe et al, 2016). Some studies use the t-test statistic and draw inference from basic inferential statistic (Aburime, 2008) Many studies use a combination of both descriptive statistics, correlation analysis and ordinary least square regression (see Paul et al, 2015; Amahalu et al, 2017; Adeneye and Ahmed; 2015; Demaki, 2018; Abdulazeez et al 2016; Ozili and Uadiale, 2017; Uwuigbe et al 2018). Only few studies use the generalized methods of moments (see. Odeleye, 2018; Abdulmalik and Ahmad, 2016; Obembe and Soetan, 2015; Obembe et al, 2016). From the above, it is 
easy to see that there are multiple inconsistent estimation techniques and methods of analysis in the Nigerian corporate governance literature. Some studies use a single estimation technique while other studies use a combination of different techniques which often produce conflicting results. When there are conflicting results from using multiple methods, authors tend to report only the results that meets their prior expectation or predictions. This does not mean that having conflicting results in empirical research is a bad thing, no not at all! What is worrisome is that the conflicting results derived from using mixed method are not well-explained by authors in their discussion of findings. To sum up, these inconsistencies in CG modelling and estimations are responsible for the mixed results in the Nigerian corporate governance literature. It might be helpful for academics investigating corporate governance in Nigeria to explain why they have conflicting results when they use different methodologies in their corporate governance research.

\section{Other observations and directions for future research}

\subsection{Much research on non-financial firms compared to financial firms}

Many studies investigate corporate governance in non-financial firms such as manufacturing companies, textile companies, oil companies, etc, while there are fewer studies investigating CG outcomes in the different types of financial firms in Nigeria. There are different types of financial institutions in Nigeria, and future research should explore the effect of CG on the performance of these financial institutions. More research on financial firms is needed particularly research that compare the effect of CG on insurance firms, mutual funds companies and pension companies. Such studies can help us understand whether the adoption of the same CG codes by financial firms have the same or dissimilar effect on the different type of financial firms such as pension companies, mutual funds, insurance companies, etc.

\subsection{Ignoring other governance mechanisms}

The Nigerian CG literature focuses extensively on some governance mechanisms such as Board characteristics and shareholder ownership structure. The literature also ignores other governance mechanisms in firms such as the 'comply-or-explain' regulatory style of regulators, CEO characteristics, top management team characteristics and state-ownership of Nigerian firms. Scholars investigating CG in Nigeria should extend their research to these areas to provide additional insight into how different governance mechanisms affect the performance of firms in Nigeria.

\subsection{Much focus on the Board of directors}

The Board of directors (BOD) is the most explored corporate governance mechanism in the Nigerian corporate governance literature. Although the Board of directors play an important role in the 
management of financial and non-financial firms, it is important to stress that the activities of the Board of directors do not occur in a vacuum and the role of the Board often interact with other governance mechanisms such as CEO, owners, top management teams, capital markets and regulator's requirement. Therefore, future studies investigating the impact of CG on firm performance should consider the interaction between Board composition and other corporate governance determinants.

\subsection{Scant research on CG in SMEs.}

Another area of concern is corporate governance research in small and medium scale enterprises (SMEs). SMEs are catalysts for economic growth and their survival and performance depends on how they are managed to reach their full potential. Many SMEs in Nigeria exist as one-man businesses or exist as partnerships. A large number of SMEs fail while only a few succeed. CG in SMEs is one explanation for the high rate of failure of SMEs in Nigeria yet there is little or no studies investigating the impact of CG on the survival and performance of SMEs in Nigeria. Future studies should examine the role of CG on the performance of SMEs bearing in mind the different business structure of SMEs in the country. Such studies should conduct empirical analyses using available data rather than descriptive discussions.

\subsection{Non-financial measures of performance}

Most of the Nigerian CG literature extensively focus on the effect of CG on financial performance with little focus on non-financial performance. Although financial performance is important, financial performance has a major weakness - it does not capture the effort that companies put in to improve customer experience, community development, employee welfare, corporate social responsibility, etc. Some non-financial measures of performance include employee satisfaction, customer satisfaction, firm reputation, reduced litigation against the firm, etc. Non-financial measures of performance are important because when there are two equally profitable firms, an investor is more likely to choose the company that has a higher non-financial measure performance particularly ethical investors. Future studies should investigate whether good CG leads to higher non-financial performance in Nigerian firms. Non-financial measures of performance may be considered in isolation or together with financial performance when investigating the link between firm performance and CG.

\section{6. $\mathrm{CG}$ and non-linearity}

Finally, there are some non-linear relationships between each CG determinants and between CG and firm performance. The non-linear relationships reflect the complex and intertwined relationship between each CG determinants and other outcomes. Future studies should use non-linear or dynamic models to test the non-monotonic relationships between each CG determinants, and the potential nonlinear relationship between CG and firm performance. Also, these model specifications should be wellgrounded in theory or at least be grounded in complete theory-based hypothesis development. 
Qualitative methods of inquiry can also be used to examine non-linear relationship between CG and firm performance.

\section{Closing Remarks and conclusion}

This systematic literature review analyzes the corporate governance literature in Nigeria. The review shows that agency theory and resource theory are the most frequently used theoretical perspectives in the literature. Most empirical research focus extensively on CG in non-financial firms while only a few papers use data from financial firms and SMEs. Studies employ a variety of correlation and regression methods, only a few research papers use non-linear models to capture non-linearity in the relationship between CG ad firm performance. Most articles are merely descriptive discussions on CG issues. On the basis of the literature review, I proposed several directions for future research. 


\section{Reference}

Abdulazeez, D. A., Ndibe, L., \& Mercy, A. M. (2016). Corporate governance and financial performance of listed deposit money banks in Nigeria. Journal of Accounting and Marketing, 5(1), 1-6.

Abdulmalik, S. O., \& Ahmad, A. C. (2016). Corporate Governance and Financial Regulatory Framework in Nigeria: Issues and Challenges. Journal of Advanced Research in Business and Management Studies, 2, 50-63.

Abor, J., \& Adjasi, C. K. (2007). Corporate governance and the small and medium enterprises sector: theory and implications. Corporate Governance: The International Journal of Business in Society, 7(2), $111-122$.

Abdulmalik, O., \& Ahmad, A. C. (2016). Audit Fees, Corporate Governance Mechanisms, and Financial Reporting Quality in Nigeria. DLSU Business \& Economics Review, 26(1).

Aburime, T. (2008). Impact of ownership structure on bank profitability in Nigeria. Available at SSRN 1107760. Available at SSRN: https://ssrn.com/abstract $=1107760 \quad$ or http://dx.doi.org/10.2139/ssrn.1107760

Adebimpe, D. U., \& Peace, O. (2011). Corporate governance, company attributes and voluntary disclosures: A study of Nigerian listed companies.

Adegbite, E. (2012). Corporate governance regulation in Nigeria. Corporate Governance: The international journal of business in society, 12(2), 257-276.

Adegbite, E., \& Nakajima, C. (2011). Institutional determinants of good corporate governance: The case of Nigeria. In Firm-level internationalization, regionalism and globalization (pp. 379-396). Palgrave Macmillan, London.

Adegbite, E., Amaeshi, K., \& Nakajima, C. (2013). Multiple influences on corporate governance practice in Nigeria: Agents, strategies and implications. International Business Review, 22(3), 524-538.

Adekoya, A. A. (2011). Corporate governance reforms in Nigeria: Challenges and suggested solutions. Journal of Business systems, governance and ethics, 6(1), 38-50. 
Adekunle, S. A., and Aghedo, E. M. (2014). Corporate governance and financial performance of selected quoted companies in Nigeria. European Journal of Business and Management, 6(9).

Adeneye, Y. B., \& Ahmed, M. (2015). Corporate social responsibility and company performance. Journal of Business Studies Quarterly, 7(1), 151.

Adenikinju, O. (2012). Managerial characteristics, corporate governance and corporate performance: The case of Nigerian quoted companies. AERC Research Paper 241, African Economic Research Consortium, Nairobi. August.

Adigwe, P. K., Onyenwe, N. I., \& John, E. I. (2016). Effect of Corporate Governance Mechanism on the Financial Performance of Banks in Nigeria. NG-Journal of Social Development, 417(3768), 1-10.

Aguilera, R. V., Judge,W. Q., \& Terjesen, S. A. (2018). Corporate governance deviance. Academy of Management Review, 43(1), 87-109.

Amahalu, N., Abiahu, M. F. C., Nweze, C., \& Chinyere, O. (2017). Effect of corporate governance on borrowing cost of quoted brewery firms in Nigeria (2010-2015).

Ahn, M. J. (2014). Enhancing corporate governance in high-growth entrepreneurial firms. International Journal of Innovation and Technology Management, 11(6).

Ahunwan, B. (2002). Corporate governance in Nigeria. Journal of Business Ethics, 37(3), 269-287.

Babatunde, M. A., \& Olaniran, O. (2009). The effects of internal and external mechanism on governance and performance of corporate firms in Nigeria. Corporate ownership \& control, 7(2), 330344.

Claessens, S., \& Yurtoglu, B. B. (2013). Corporate governance in emerging markets: a survey. Emerging Markets Review, 15, 1-33.

Clarke, T. 2004. Theories of Corporate Governance. The Philosophical Foundations of Corporate Governance. London: Routledge.

Cowling, M. (2003). Productivity and corporate governance in smaller firms. Small Business Economics, 20(4), 335-344. 
Damagum, Y. M., Oba, V. C., Chima, E. I., \& Ibikunle, J. I. D. E. (2014). Women in corporate boards and financial reporting credibility: Evidence from Nigeria. International Journal of Accounting and Financial Management Research, 4(1), 1-8.

Del Brio, E.B., Maria-Ramires, E. \& Perote, J. 2006. Corporate governance mechanisms and their impact on firm value. Corporate Ownership and Control, 4(1): 25-36.

DeZoort, F., \& Hermanson, D. (2002). Audit committee effectiveness: a synthesis of the empirical audit committee literature.

Demaki, G. O. (2018). Corporate Governance and Banks Profitability In Nigeria. Archives of Business Research, 6(4).

Dibia, N. O., \& Onwuchekwa, J. C. (2014). An appraisal of corporate governance mechanisms and earnings management in Nigeria. International Journal of Finance and Accounting, 3(2), 49-59.

Ehikioya, B. I. (2009). Corporate governance structure and firm performance in developing economies: evidence from Nigeria. Corporate Governance: The international journal of business in society, 9(3), 231-243.

Fama, E. F., \& Jensen, M. C. (1983). Separation of ownership and control. Journal of Law and Economics, 26(2), 301-325.

Fodio, M. I., Ibikunle, J., \& Oba, V. C. (2013). Corporate governance mechanisms and reported earnings quality in listed Nigerian insurance firms. International Journal of Finance and Accounting, 2(5), 279-286.

Adefemi, F., Hassan, A., \& Fletcher, M. (2018). "Corporate Governance Disclosure in Nigerian listed Companies". International Research Journal of Business Studies, 11(2), 67-80.

Foyeke, O. I., Iyoha, F. O., \& Ojeka, S. (2015). Firm size and financial performance: A determinant of corporate governance disclosure practices of Nigerian companies. Journal of Accounting and Auditing: Research \& Practice.

Ge, J., Stanley, L. J., Eddleston, K., \& Kellermanns, F.W. (2017). Institutional deterioration and entrepreneurial investment: the role of political connections. Journal of Business Venturing, 32 (4) , 405-419 
Gugong, B. K., Arugu, L. O., \& Dandago, K. I. (2014). The impact of ownership structure on the financial performance of listed insurance firms in Nigeria. International Journal of Academic Research in Accounting, Finance and Management Sciences, 4(1), 409-416.

Isaac, J. E., \& Nkemdilim, I. S. (2016). Corporate governance and the performance of Nigerian banks. International Journal of Economics, Finance and Management Sciences, 4(2), 39-45.

Jensen, M. C., \& Meckling, W. H. (1976). Theory of the firm: managerial behavior, agency costs and ownership structure. Journal of Financial Economics, 3(4), 305-360.

Joe Duke, I. I., \& Kankpang, K. A. (2011). Linking corporate governance with organizational performance: New insights and evidence from Nigeria. Global Journal of Management and Business Research, 11(12).

John, K., \& Senbet, L. W. (1998). Corporate governance and board effectiveness. Journal of Banking \& Finance, 22(4), 371-403.

Kajola, S. O. (2008). Corporate governance and firm performance: The case of Nigerian listed firms. European journal of economics, finance and administrative sciences, 14(14), 16-28.

Kantudu, A. S., \& Samaila, I. A. (2015). Board Characteristics, Independent Audit Committee and Financial Reporting Quality of Oil Marketing Firms: Evidence from Nigeria. Journal of Finance, Accounting \& Management, 6(2).

Keasey, K., Short, H., \&Watson, R. (1994). Directors' ownership and the performance of small and medium sized firms in the UK. Small Business Economics, 6(3), 225-236.

Klein, A. (2002). Audit committee, board of director characteristics, and earnings management. Journal of accounting and economics, 33(3), 375-400.

Kor, Y. Y.,\&Mahoney, J. T. (2005).How dynamics,management, and governance of resource deployments influence firm-level performance. Strategic Management Journal, 26(5), 489-496.

Kroll, M., Walters, B. A., \& Le, S. A. (2007). The impact of board composition and top management team ownership structure on post-IPO performance in young entrepreneurial firms. Academy of Management Journal, 50(5), 1198-1216. 
Letza, S. (2017). Corporate governance and the African business context: The case of Nigeria. Economics and Business Review, 3(1).

Leuz, C., Nanda, D., \& Wysocki, P. D. (2003). Earnings management and investor protection: an international comparison. Journal of financial economics, 69(3), 505-527.

Lynall, M. D., Golden, B. R., \& Hillman, A. J. (2003). Board composition from adolescence to maturity: a multitheoretic view. Academy of Management Review, 28(3), 416-431.

Miko, N. U., \& Kamardin, H. (2015). Impact of audit committee and audit quality on preventing earnings management in the pre-and post-Nigerian corporate governance code 2011. Procedia-Social and Behavioral Sciences, 172, 651-657.

Mohammed, F. (2012). Impact of corporate governance on banks performance in Nigeria. Journal of Emerging Trends in Economics and Management Sciences, 3(3), 257-260.

Moses, T. E. M. P. L. E., Ofurm, C., \& Egbe, D. S. (2016). Audit committee characteristics and quality of financial reporting in quoted Nigerian banks. International Journal of Advanced Academic Research, 2(5), 1-10.

Nakpodia, F., Adegbite, E., Amaeshi, K., \& Owolabi, A. (2018). Neither principles nor rules: Making corporate governance work in Sub-Saharan Africa. Journal of Business Ethics, 151(2), 391-408.

Nwaiwu, J. N., \& Joseph, B. (2018). Core Corporate Governance Structure and Financial Performance of Manufacturing Companies in Nigeria.

Nwidobie, B. M. (2016). Corporate governance practices and dividend policies of quoted firms in Nigeria. International Journal of Asian Social Science, 6(3), 212-223.

Obembe, O. B., \& Soetan, R. O. (2015). Competition, corporate governance and corporate performance: substitutes or complements? Empirical evidence from Nigeria. African Journal of Economic and Management Studies, 6(3), 251-271.

Obembe, O. B., Olaniyi, C. O., \& Soetan, R. O. (2016). Managerial ownership and performance of listed non-financial firms in Nigeria. International Journal of Business and Emerging Markets, 8(4), 446-461. 
Odeleye, A. T. (2018). Quality of Corporate Governance on Dividend Payouts: The Case of Nigeria. African Development Review, 30(1), 19-32.

Odoemelam, N., \& Okafor, R. G. (2018). The influence of corporate governance on environmental disclosure of listed non-financial firms in Nigeria. Indonesian Journal of Sustainability Accounting and Management, 2(1), 25-49.

Ogbechie, C., \& Koufopoulos, D. N. (2007). Corporate governance practices in publicly quoted companies in Nigeria. International Journal of Business Governance and Ethics, 3(4), 350-381.

Ojeka, S., Iyoha, F. O., \& Obigbemi, I. F. (2014). effectiveness of audit committee and firm financial performance in Nigeria: an empirical analysis. Journal of Accounting and Auditing: Research \& Practice.

Ojeka, S., Fakile, A. S., Ikpefan, O. A., \& Achugamonu, B. U. (2016). Institutional Shareholder Engagement, Corporate Governance and Firms' Financial Performance in Nigeria: Does any relationship exist? Journal of Internet Banking and Commerce, 21(2).

Okike, E. N. (2007). Corporate governance in Nigeria: The status quo. Corporate Governance: An International Review, 15(2), 173-193.

Okpara, G. C., \& Iheanacho, E. (2014). Banking Sector Performance and Corporate Governance in Nigeria: A Discriminant Analytical Approach. Expert Journal of Finance, 2, 10-17.

Okpara, G. C. (2016). Banking sector performance and corporate governance in Nigeria.

Onakoya, A. B. O., Fasanya, I. O., \& Ofoegbu, D. I. (2014). Corporate Governance as Correlate for Firm Performance: A Pooled OLS Investigation of Selected Nigerian Banks. IUP Journal of Corporate Governance, 13(1).

Osemeke, L., \& Adegbite, E. (2016). Regulatory multiplicity and conflict: towards a combined code on corporate governance in Nigeria. Journal of business ethics, 133(3), 431-451.

Owolabi, S. A., \& Dada, S. O. (2011). Audit committee: An instrument of effective corporate governance. European Journal of Economics, Finance and Administrative Sciences, 35(35), 174-183. 
Oyejide, T. A., \& Soyibo, A. (2001, January). Corporate governance in Nigeria. In Conference on Corporate Governance, Accra, Ghana (Vol. 29, p. 30).

Oyewunmi, O. A., Adeyemi, K. S., \& Ogunnaike, O. O. (2017). Corporate governance and human resource management in Nigeria's downstream petroleum sector. Scientific Annals of Economics and Business, 64(2), 139-153.

Ozili, P. K. (2017). Bank earnings smoothing, audit quality and procyclicality in Africa: the case of loan loss provisions. Review of Accounting and Finance, 16(2), 142-161.

Ozili, P. K., \& Outa, E. (2017). Bank loan loss provisions research: A review. Borsa Istanbul Review, 17(3), 144-163.

Ozili, P. K., \& Uadiale, O. (2017). Ownership concentration and bank profitability. Future Business Journal, 3(2), 159-171.

Ozili. P.K., \& Thankom, T. G. (2018). Income smoothing among European systemic and non-systemic banks. The British Accounting Review, 50(5), 539-558.

Patrick, E. A., Paulinus, E. C., \& Nympha, A. N. (2015). The influence of corporate governance on earnings management practices: a study of some selected quoted companies in Nigeria. American Journal of Economics, Finance and Management, 1(5), 482-493.

Paul, G. D., Ebelechukwu, E. C., \& Yakubu, S. (2015). Impact of corporate governance on financial performance of microfinance banks in north central Nigeria. International Journal of Humanities Social Sciences and Education, 2(1), 153-170.

Reid, A.S. 2003. The internationalisation of corporate governance codes of conduct. Business Law Review, 24:233-238.

Sanda, A. U., Mikailu, A. S., \& Garba, T. (2005). Corporate governance mechanisms and firm financial performance in Nigeria.

Shittu, I., Ahmad, A. C., \& Ishak, Z. (2018). Audit committee independence, abnormal directors compensation, corporate governance disclosure and price to earnings multiple of Nigerian firms. Journal for Global Business Advancement, 11(2), 156-172. 
Salterio, S., Conrad, J. \& Schmidt, R. 2013. Canadian evidence of adherence to "comply or explain" corporate governance codes: An international comparison. Accounting Perspectives, 12(1): 23-51.

Uadiale, O. M. (2010). The impact of board structure on corporate financial performance in Nigeria. International Journal of Business and Management, 5(10), 155.

Ujunwa, A. (2012). Board characteristics and the financial performance of Nigerian quoted firms. Corporate Governance: The international journal of business in society, 12(5), 656-674.

Usman, S. H., \& Yero, J. I. (2012). Ownership concentration and earnings management practice of Nigerian listed conglomerates. American International journal of contemporary Research, 2(7), 157171.

Usman, A. B., \& Amran, N. A. B. (2015). Corporate social responsibility practice and corporate financial performance: evidence from Nigeria companies. Social Responsibility Journal, 11(4), 749763.

Usman, S. H., \& Yero, J. I. (2012). Ownership concentration and earnings management practice of nigerian listed conglomerates. American International journal of contemporary Research, 2(7), 157171.

Uwalomwa, U., Olamide, O., \& Francis, I. (2015). The Effects of Corporate Governance Mechanisms on Firms Dividend Payout Policy in Nigeria. Journal of Accounting and Auditing, 2015, 1.

Uwuigbe, U., Eluyela, D. F., Uwuigbe, O. R., Obarakpo, T., \& Falola, I. (2018). Corporate governance and quality of financial statements: a study of listed Nigerian banks. Banks Bank Syst, 13(3), 12-23.

Uwuigbe, U., Peter, D. S., \& Oyeniyi, A. (2014). The effects of corporate governance mechanisms on earnings management of listed firms in Nigeria. Accounting and Management Information Systems, 13(1), 159-174.

Uwuigbe, O. R. (2013). Corporate governance and share price: Evidence from listed firms in Nigeria. African Research Review, 7(2), 129-143.

Von Werder, A., Talaulicar, T. \& Kolat, G. (2005). Compliance with the German Corporate Governance Code: An empirical analysis of the compliance statements by German listed companies. Corporate Governance: An International Review, 13(2): 178-187. 
Xie, B., Davidson III, W. N., \& DaDalt, P. J. (2003). Earnings management and corporate governance: the role of the board and the audit committee. Journal of corporate finance, 9(3), 295-316.

Yakasai, A. G. (2001). Corporate governance in a third world country with particular reference to Nigeria. Corporate Governance: An International Review, 9(3), 238-253.

Zattoni, A., Witt, M. A., Judge, W. Q., Talaulicar, T., Chen, J. J., Lewellyn, K., et al. (2017). Does board independence influence financial performance in IPO firms? The moderating role of the national business system. Journal of World Business, 52(5), 628-639.

Zattoni, A. \& Cuomo, F. (2008). Why adopt codes of good governance? A comparison of institutional and efficiency perspectives, Corporate Governance: An International Review, 16 (1): 1-16. 